PENELITIAN

\title{
RASIO NETROFIL LIMFOSIT DAN LIMFOSITOPENIA SEBAGAI PENANDA SEPSIS
}

\section{NEUTROPHYL LYMPHOCYTE RATIO AND LIMFOSITOPENIA AS A PREDICTOR SEPSIS}

\author{
Puja Laksana Maqbul *, Ery Leksana **, M. Sofyan Harahap ** \\ * PPDS1 Bagian Anestesi dan Terapi Intensif Fakultas Kedokteran Universitas Diponegoro / RSUP Dr. Kariadi \\ Semarang \\ ** Staff Pengajar Bagian Anestesi dan Terapi Intensif Fakultas Kedokteran Universitas Diponegoro / RSUP Dr. \\ Kariadi Semarang \\ *Korespondensi/Correspondence: puja.laksana@gmail.com
}

\section{ABSTRACT}

Background: The state of sepsis will initially lead to an increase in the number of neutrophils followed by an increase in lymphocytes, a state of sepsis that last longer will cause apoptosis of lymphocytes, so that the neutrophil lymphocyte ratio will increase, and absolute limfositopenia will occur which can be used as an indicator of sepsis.

Objective: Knowing the value of RNL and lymphocyte count in patients suspected of sepsis in the ICU Dr. Kariadi Hospital Semarang

Methods: This study is a non-experimental diagnostic and cross sectional design with a sample of 30 patients. Blood samples were taken from ICU patients with two or more signs of SIRS and suspected infection for leukocyte count and blood culture examination, then the data were analyzed using ROC curves.

Result: The source of infection occurred in the digestive tract (43.3\%), obstetrics gynecology (23.3\%), respiratory tract $(16.7 \%)$, cerebrovascular $(10 \%)$ and urinary tract (6.7\%). NeutrophilsLymphocytes count ratio hasAUC 0,425 (sensitivity 60\% and specificity 20\%), absolute Limfositopenia has AUC 0,425 (sensitivity 40\% and specificity 40\%), while the RNL and Limfositopenia has AUC 0.575 (sensitivity 70\% and specificity $45 \%$ ).

Conclusion:Neutrophils Lymphocytes count ratio and absolute Lymphocytopenia can not be used as an indicator of sepsis in ICU's patients despite having a sensitivity of $70 \%$ and specifity $45 \%$.

Keywords: Sepsis, Ratio Neutrophils Lymphocytes, Limfositopenia absolute.

\begin{abstract}
ABSTRAK
Latar Belakang: Keadaan sepsis pada awalnya akan menyebabkan peningkatan jumlah netrofil diikuti oleh peningkatan limfosit, keadaan sepsis yang bertahan akan menyebabkan apoptosis dari limfosit, sehingga rasio netrofil limfosit akan meningkat, dan terjadi limfositopenia yang dapat dijadikan indikator sepsis.

Tujuan: Mengetahui nilai RNL dan hitung limfosit pada pasien dicurigai sepsis di RSUP Dr. Kariadi Semarang

Metode: Penelitian ini merupakan penelitian diagnostik non eksperimental dengan desain cross sectional dengan jumlah sampel 30 pasien. Pasien ICU dengan dua atau lebih tanda SIRS dan dicurigai infeksi diambil sampel darah untuk dilakukan pemeriksaan hitung jenis leukosit dan pemeriksaan kultur darah, kemudian data dianalisis menggunakan kurva ROC.
\end{abstract}


Hasil: Sumber infeksi terbanyak terjadi pada traktus digestivus $(43,3 \%)$, obstetri ginekologi $(23,3 \%)$, traktus respiratorius $(16,7 \%)$, cerebrovaskular $(10 \%)$ dan traktus urinarius (6,7\%). Rasio Netrofil Limfosit memiliki AUC 0,425 (sensitivitas 60\% dan spesifitas 20\%), Limfositopenia absolut memiliki AUC 0,425 (sensitivitas 40\% dan spesifitas 40\%), sedangkan RNL dan Limfositopenia memiliki AUC 0,575 (sensitivitas $70 \%$ dan spesifitas $45 \%$ ).

Kesimpulan: Rasio Netrofil Limfosit dan Limfositopenia absolut tidak bisa dijadikan indikator sepsis pada pasien-pasien di ICU walaupun memiliki sensitivitas $70 \%$ dan spesisifitas $45 \%$.

Kata kunci: Sepsis, Rasio Netrofil Limfosit, Limfositopenia absolut.

\section{PENDAHULUAN}

Sepsis merupakan sindrom klinis yang termasuk komplikasi infeksi berat dan ditandai dengan inflamasi sistemik dan kerusakan jaringan yang luas. Jaringan yang jauh dari fokus infeksi, menunjukkan tanda-tanda utama inflamasi, termasuk vasodilatasi, peningkatan permeabilitas mikrovaskular, dan akumulasi leukosit. $^{1}$

Angka kejadian sepsis di ruang ICU RSUP Dr. Kariadi Semarang selama tahun 2013-2014 awal adalah 70 kasus (data rekam medik RSUP Dr. Kariadi Semarang).Penelitian Angus et al (2001) menyebutkan angka kematian $20-52 \%$ pada pasien dengan sepsis berat, $^{2}$ sedangkan VanGestel et al menunjukkan angka kematian untuk penderita dengan sepsis berat adalah sebesar $56 \%{ }^{3}$

Diagnosis sepsis ditegakkan bila diduga atau terbukti infeksi dan terdapat dua atau lebih kriteria berikut, (1) suhu $>38,3^{\circ} \mathrm{C}$ atau $<36^{\circ} \mathrm{C}$, (2) laju jantung $>90 \mathrm{x} /$ menit, (3) laju pernapasan $>20 \mathrm{x} /$ menit atau $\mathrm{PaCO}_{2}<32 \mathrm{mmHg}$, (4) total hitung leukosit $<4.000 / \mu \mathrm{L}$ atau $>$

\section{$12.000 / \mu \mathrm{L}^{4}$}

Sepsis didefinisikan sebagai adanya (diduga atau terbukti) infeksi yang disertai dengan manifestasi sistemik dari infeksi. ${ }^{5}$ Penyebab sepsis terbanyak adalah infeksi pada (1) paruparu, (2) saluran urogenital, (3) intra abdomen.Sepsis masih merupakan tantangan klinis utama yang imbasnya pada medis dan ekonomi masih dianggap remeh.Diagnosis klinis penting untuk pengenalan awal dari gambaran klinis yang sedang terjadi sehingga terapi intervensi bisa segera dikerjakan. ${ }^{6}$

Kultur darah masih menjadi "Gold standard" untuk mengkonfirmasi keadaan klinis yang dicurigai sepsis. Klinisi tidak mempunyai waktu yang cukup untuk menunggu hasil kultur darah yang membutuhkan waktu relatif lama. $^{6}$

Selama stress atau infeksi, jumlah neutrofil mature yang masuk ke sirkulasi sedikit, termasuk peningkatan jumlah dari band. Hal ini dinamakan shift to the left yang didefinisikan sebagai peningkatan rasio immature/ total granulocyte atau peningkatan 
jumlah band neutrofil. ${ }^{7}$ Rasio Neutrofil Limfosit (RNL) telah terbukti memiliki nilai prognostik pada beberapa jenis kanker dan juga berguna untuk mendiagnosis appendicitis akut, pankreatitis akut, colitis ulcerative dan community acquired pneumonia (CAP). ${ }^{8}$

Limfositopenia absolut (jumlah limfosit $<1$ x $\left.10^{9} / \mathrm{L}\right)$ berguna untuk memprediksi keadaan bakteremia pada pasien dengan toxic shock syndrome, pasien di Intensive Care Unit (ICU) onkologi dan pasien gawat darurat. ${ }^{9}$

Keadaan sepsis pada awalnya akan menyebabkan peningkatan jumlah netrofil diikuti oleh peningkatan limfosit, keadaan sepsis yang bertahan akan menyebabkan apoptosis dari limfosit, ${ }^{10}$ sehingga rasio netrofil limfosit akan meningkat dan dapat dijadikan indikator sepsis.

Berdasarkan hal tersebut di atas, peneliti ingin mengetahui sensitivitas dan spesifitas dari RNL dan limfositopenia sebagai penanda sepsis di ICU RSUP Dr. Kariadi. Peneliti tertarik dengan RNL dan limfositopenia sebagai indikator sepsis karena pemeriksaan ini relatif lebih mudah dan murah dibandingkan dengan pemeriksaan procalcitonin.

\section{METODE}

Penelitian ini merupakan penelitian diagnostik non eksperimental dengan desain cross sectional yang bertujuan untuk mengetahui sensitivitas dan spesifitas dari RNL dan limfositopenia terhadap kejadian sepsis di ICU RSUP DR. Kariadi.

Penelitian dilakukan di Instalasi Rawat Intensif(Intensive Care Unit (ICU))RSUP Dr. Kariadi Semarang dan pemeriksaan laboratorium di Laboratorium Patologi Klinik RSUP Dr. Kariadi Semarang dan laboratorium Mikorbiologi RSUP Dr. Kariadi Semarang.

Penentuan besar sampel penelitian ini menggunakan rumus penelitian diagnostik dengan keluaran Area Under Curve (AUC), didapatkan jumlah sampel hasil penghitungan rumus tersebut adalah 30 pasien.

Sampel merupakan pasien di ICU RSUP Dr. Kariadi Semarang yang memenuhi kriteri inklusi: 1. pasien dewasa berumur $18-60$ tahun, 2 . pasien dirawat di unit rawat intensif, 3. pasien mempunyai 2 atau lebih tanda SIRS, 4. dicurigai adanya fokus infeksi pada pasien tersebut, dan kriteria eksklusi: 1. pasien mendapatkan terapi sitostatika, imunosupresan atau imunomodulator, 2 . pasien hipovolemia.

Pasien yang di rawat di ICU RSUP Dr. Kariadi Semarang yang memenuhi kriteria inklusi diambil sampel darah tepi dan kultur darah pada hari yang sama. Sampel diperiksa di laboratorium Patologi Klinik dan mikrobiologi RSUP Dr. Kariadi Semarang. Data dikumpulkan dan diolah menggunakan program SPSS (kurva AUC).

\section{HASIL}

Sumber infeksi pada pasien- 
pasien yang diambil sebagai sampel pada penelitian ini dikelompokkan menjadi traktus respiratorius, traktus digestivus, traktus urinarius, obstetri ginekologi dan cerebrovaskular. Jumlah kasus terbanyak pada penelitian ini berasal dari traktus digestivus (43,3\%).

Hasil perhitungan RNL pada penelitian ini dengan nilai cutoff 10 menghasilkan jumlah kasus RNL $>10$ ada 21 kasus dan yang mengalami sepsis didapatkan 6 kasus, sedangkan RNL $<10$ ada 9 kasus dan yang mengalami sepsis didapatkan 4 kasus (tabel 3). Menggunakan kurva ROC untuk menghitung AUC RNL dan sepsis didapatkan AUC sebesar 0,425 (gambar 6) dengan signifikansi $\mathrm{p}=$ 0,509 . Sensitivitas $60 \%$ dan spesifitas $25 \%$.

Keadaan limfositopenia absolut pada pasien-pasien yang mengikuti penelitian ini didapatkan pada 15 pasien dan yang mengalami sepsis ada 4 pasien (tabel 4). Menggunakan kurva ROC untuk menghitung AUC RNL dan sepsis didapatkan AUC sebesar 0,425 (gambar 6) dengan signifikansi $\mathrm{p}=$ 0,509 . Sensitivitas $40 \%$ dan spesifitas $45 \%$.

Pasien dengan RNL $>10$ dan dalam keadaan limfositopenia absolut didapatkan pada 12 pasien dan yang mengalami kejadian sepsis ada 3 pasien (tabel 5). Hasil statistik menggunakan ROC terhadap RNL $>10$ dan limfositopenia absolut terhadap sepsis menghasilkan area under curve (AUC) 0,575 (gambar 6) dengan signifikansi $\mathrm{p}$ $=0,509$, sensitivitas $70 \%$ dan spesifitas $45 \%$.

\section{PEMBAHASAN}

Sepsis merupakan masalah utama dari angka kesakitan dan kematian baik pada negara maju maupun negara berkembang. ${ }^{19,20}$ Angka kematian masih tinggi sekitar $30 \%$ dan meningkat menjadi $60 \%$ jika didapatkan syok septik. Bakteri masih menjadi mikroorganisme penyebab yang paling sering pada sepsis, dan kultur positif hanya terjadi pada sekitar $50 \%$ kasus. ${ }^{20}$ Angka kejadian sepsis dengan hasil kultur positif pada penelitian ini hanya 10 kasus $(33,3 \%)$ dari 30 kasus.

Hasil kultur negatif bisa terjadi pada sekitar 28\% - 48\% kasus sepsis. Hal ini dapat disebabkan oleh: ${ }^{20}$

Kultur kurang sensitif dalam mengidentifikasi semua bakteri, hal ini disebabkan oleh paparan penggunaan antibiotik sebelumnya, volume sampel darah yang kurang, kondisi tranport sampel yang tidak baik, dan pertumbuhan bakteri yang lambat, ${ }^{21}$ Polymerase Chain Reaction (PCR) merupakan teknik dengan dasar molekular bisa meningkatkan angka deteksi bakteri, dan banyak pasien dengan sepsis secara klinis memiliki PCR yang positif tapi hasil kultur yang negatif. $^{22-24}$

Beberapa pasien yang memiliki hasil kultur negatif bisa mengalami sepsis nonbakterial. Jamur bertanggungjawab pada sekitar 5\% kasus sepsis di ICU, dan secara umum lebih bisa terdeteksi dibandingkan dengan infeksi karena virus dan jamur Pasien tidak mengalami sepsis, hal ini 
dapat disebabkan karena kriteria sepsis yang kami pakai berdasarkan gabungan pengamatan klinis dan laboratoris yang pasti termasuk beberapa diagnosis yang lain, yang beberapa termasuk positif palsu dan tidak berhubungan dengan infeksi. ${ }^{25}$

Hasil kultur negatif juga dapat disebabkan oleh definisi sepsis kami yang masih terlalu luas karena masih menggunakan kriteria SIRS dan dicurigai adanya infeksi. Definisi sepsis terbaru disebutkan di konsensus sepsis3 oleh European Society of Intensive Care Medicine (ESICM) pada bulan Februari 2016, dan direspon baik oleh Surviving Sepsis Campaign (SSC) pada bulan maret 2016. Menurut SSC dan ESICM definisi sepsis terbaru secara klinis adalah perubahan SOFA skor $\geq 2$ dari nilai awalnya dan dicurigai adanya infeksi. $^{26}$

Kejadian sepsis pada penelitian ini 43,3\% bersumber dari traktus digestivus, hal ini tidak sesuai dengan penelitian Monti $G$ et al yang menyebutkan bahwa sumber infeksi sepsis terbanyak berasal dari traktus respiratorius. $^{13,14}$ Hal ini dapat disebabkan karena pasien ICU RSUP Dr. Kariadi itu banyak yang merupakan kasus post operasi sedangkan pada penelitian Monti $\mathrm{G}$ et al menggunakan jumlah sampel yang jauh lebih besar dan variasi kasus yang lebih banyak.

Rasio netrofil limfosit yang meningkat bisa menandakan bahwa pasien sedang dalam keadaan inflamasi yang masih berlangsung walaupun tidak ditemukan adanya infeksi, ${ }^{27}$ hal ini sesuai dengan hasil pada penelitian ini dari 20 pasien yang memiliki RNL > 10 , hanya 5 pasien yang sepsis dan kurva ROC RNL terhadap sepsis memiliki AUC 0,425 yang dinilai tidak baik untuk dijadikan dasar diagnosis dari sepsis.

Limfositopenia absolut pada penelitian ini terjadi pada 15 pasien dan hanya 4 pasien yang mengalami sepsis. Hal ini dapat disebabkan oleh keadaan lain selain infeksi, seperti malnutrisi. Malnutrisi sendiri dapat menyebabkan apoptosis atau mempengaruhi kematangan limfosit melalui hipoplasia sumsum tulang. ${ }^{28,29}$

Rasio netrofil limfosit dan limfositopenia menurut de Jager et al dapat dijadikan indikator adanya bakteremia pada pasien, ${ }^{9}$ tapi pada penelitian ini RNL $>10$ dan limfositopenia absolut walaupun memiliki sensitivitas $70 \%$ dan spesifitas $55 \%$ tapi dinilai tidak bermakna dan tidak baik untuk dijadikan sebagai indikator sepsis pada pasien-pasien di ICU RSUP Dr. Kariadi karena memiliki AUC 0,575.

Hal ini dapat disebabkan karena pada penelitian de Jager et al botol kultur yang digunakan adalah botol kultur untuk bakteri aerob dan bakteri anaerob, sedangkan di ICU RSUP Dr. Kariadi botol sampel kultur yang digunakan hanya botol kultur yang untuk bakteri aerob,sehingga bakteribakteri yang anaerob obligat tidak dapat tumbuh di media tersebut.

\section{SIMPULAN}

Pasien dicurigai sepsis yang memiliki nilai $\mathrm{RNL}>10$ dan hitung 
jumlah limfosit $<1000$ tidak semuanya terbukti sepsis.Rasio netrofil limfosit $>$ 10 dan hitung jumlah limfosit $<1000$ memiliki sensitivitas $70 \%$ dan spesifitas $45 \%$ terhadap kejadian sepsis dan belum bisa dijadikan sebagai penanda sepsis pada pasien yang dicurigai sepsis.

\section{DAFTAR PUSTAKA}

1. Chang HJ, Sinha S, Moss M. Patient page: Sepsis. J Am Med Association 2010;304:1856-7

2. Angus DC, Linde-Zwirble WT, Lidicker J, Clermont G, Carcillo J, Pinsky MR: Epidemiology of severe sepsis in the United States: analysis of incidence, outcome, and associated costs of care. Crit Care Med 2001, 29:1303-1310

3. Van Gestel A, Bakker J, Veraart CPWM, Van Hout BA. Prevalence and incidence of severe sepsis in Dutch intensive care units. Critical Care 2004, 8:R153-62

4. Soong J, Soni N. Sepsis: recognition and treatment. Clinical Medicine 2012;12:276-80.

5. Dellinger RP, Levy MM, Rhodes A, Annane D, et al. Surviving Sepsis Campaign: International Guidelines for Management of Severe Sepsis and Septic Shock: 2012. Critical Care Medicine. February 2013. 41: 2. 583-5.

6. Nicasio Mancini (ed.), Sepsis: Diagnostic Methods and Protocols, Methods in Molecular Biology, vol. 1237. Springer Science Business Media. New York. 2015.

7. Park et al. Delta neutrophil index as an early marker ofdisease severity in critically ill patients with sepsis BMC Infectious Diseases, 11:299. 2011

8. Xia $\mathrm{Y}$ et al. Neutrophil Count to Lymphocyte Count Ratio is a Potential Diagnostic Index for Bacteremia in Adult.Life Science Journal. 2014;11(1). 172-7.

9. De Jager et al.Lymphocytopenia and neutrophil-lymphocyte count ratio predict bacteremia better than conventional infection markers in an emergency care unit. Critical Care 2010, 14:R192.

10.Okashah AS et al. Ratio of Neutrophil to Lymphocyte Counts as a Simple Marker for Sepsis and Severe Sepsis in Intensive Care Unit. Research and 
Opinion in Anesthesia \& Intensive Care. 2014.

11.Forget et al. Is the Neutrophil-toLymphocyte Ratio more correlated than C-reactive protein with postoperative complications after major abdominal surgery?. PeerJ. 2015

12.Yao YM et al. Sepsis Diagnostic Method and Protocols. Pathophysiological Aspects of Sepsis: An Overview. Springer Science Business Media. New York. 2015

13.Monti $G$ et al. Sepsis Diagnostic Method and Protocols. Clinical Aspects of Sepsis: An Overview. Springer Science Business Media. New York. 2015

14.Lowsby R., Gomes C, Jarman I, Lisboa P, Nee PA, Vardhan M, Eckersly T, Saleh R, Mills H. Neutrophil to Lymphocyte Count Ratio as an Early Inicator of Blood Stream Infection in the Emergency Department. Emerg Med J. 2015; 32(7): 531-534

15.Ishizuka M, Shimizu T, Kubota K. Neutrophil-to-lymphocyte ratio has a close association with gangrenous appendicitis in patients undergoing appendectomy. Int Surg 2012;97:299304.

16.Okyay GU, Inal S, Onec $\mathrm{K}$, et al. Neutrophil to lymphocyte ratio in evaluation of inflammation in patients with chronic kidney disease. Ren Fail 2013;35:29-36.

17.Pablo RD, Monserrat J, Prieto A, Alvarez M. Role of Circulating Lymphocytes in Patients with Sepsis. BioMed Research International 2014.
18.Angus CD, Poll T. Severe Sepsis and Septic Shock.N Engl J Med 2013;369:840-51.

19.Russell JA: Management of sepsis. N Engl J Med 2006, 355:1699-1713.

20.Phua et al.: Characteristics and outcomes of culture-negative versus culture-positive severe sepsis. Critical Care 2013 17:R202

21.Lever A, Mackenzie I: Sepsis: definition, epidemiology, and diagnosis. BMJ 2007, 335:879-883

22.Dark PM, Dean P, Warhurst G: Benchto-bedside review: the promise of rapid infection diagnosis during sepsis using polymerase chain reactionbased pathogen detection. Crit Care 2009, $13: 217$

23.Bloos F, Hinder F, Becker K, Sachse S, Mekontso Dessap A, Straube E, Cattoir V, Brun-Buisson C, Reinhart K, Peters $\mathrm{G}$, Bauer $\mathrm{M}$ : A multicenter trial to compare blood culture with polymerase chain reaction in severe human sepsis. Intensive Care Med 2010, 36:241-247.

24.Louie RF, Tang Z, Albertson TE, Cohen S, Tran NK, Kost GJ: Multiplex polymerase chain reaction detection enhancement of bacteremia and fungemia. Crit Care Med 2008, 36:1487 -1492 .

25.Calandra T, Cohen J: The international sepsis forum consensus conference on definitions of infection in the intensive care unit. Crit Care Med 2005, 33:15381548

26.Seymour CW, Liu VX, Iwashyna TJ, et al. Assessment of clinical criteria for sepsis: for the third international consensus definition for sepsis and 
septic shock (Sepsis-3). JAMA. 2016 Feb 23;315(8):762-774

27.Liu x, Shen $Y$, Wang H, Ge Q, Fei A, Pan S. Prognostic Significance of Neutrophil-to-Lymphocyte Ratio in Patients with Sepsis: A Prospective Observational Study. Mediators of Inflammation. Hindawi Publishing Corporation. 2016.

28.Tamhane UU, Aneja S, Montgomery D, Rogers EK, Eagle KA, Gurm HS: Association between admission neutrophil to lymphocyte ratio and outcomes in patients with acute coronary syndrome. Am J Cardiol 2008, 102:653-657.

29.Halazun KJ, Hardy MA, Rana AA, Woodland DCt, Luyten EJ, Mahadev S,
Witkowski P, Siegel AB, Brown RS Jr, Emond JC: Negative impact of neutrophil-lymphocyte ratio on outcome after liver transplantation for hepatocellular carcinoma. Ann Surg 2009, 250:141-151 